Jurnal Qua Teknika, Vol. 8 No. 1 Maret 2018

p-ISSN: 2088-2424; e-ISSN: 2527-3892

Fakultas Teknik Universitas Islam Balitar, Blitar

Http://qua.unisbablitar.ejournal.web.id; Email; quateknika@Gmail.com

Achendri M. Kurniawan, Sindy Sunjaya. 2018. Penambahan abu padam serbuk kayu mahoni sisa pemasakan tahu sebagai bahan imbuh pasir dalam meningkatkan kuat tekan bata ringan.

Jurnal Qua Teknika, (2018), 8 (1) : 42-53

\title{
PENAMBAHAN ABU PADAM SERBUK KAYU MAHONI \\ SISA PEMASAKAN TAHU SEBAGAI BAHAN IMBUH PASIR DALAM MENINGKATKAN KUAT TEKAN BATA RINGAN
}

\author{
Achendri M. Kurniawan, Sindy Sunjaya \\ Program Studi Teknik Sipil, Fakultas Teknik, Universitas Islam Balitar \\ Jl. Majapahit No. 4 Blitar Jawa Timur \\ Email : achendri.ac@Gmail.com
}

\begin{abstract}
Blitar city experienced a fairly rapid development in the field of trade. One of them is handicraft industry from wood, especially kendang jimbe. The area that is quite famous as a producer of jimbe kendang is Tanggung Village, Kepanjenkidul Subdistrict, Blitar City. In this area most of the people work as kendang craftsmen, is also a center of handicraft lathe in Blitar City. Basically, Blitar people earn from this activity, in this case people can not make good use of the rest of the activity, especially the utilization of ash of burning of mahogany powder. Of the abundant ash of the combustion of mahogany wood is expected to be used as an additional mixture of lightweight concrete. The method used in this study using laboratory experiments and guided on SNI 03-06912000. Mixture of mahogany ash dust, and know the compressive strength of lightweight brick with dust ash material as added sand material $0 \%, 25 \%, 50 \%$. From this comparison can be generated as follows: The use of ash of dried mahogany ash adds fine aggregate material (sand) in concrete brick mixture at 7 days old for $0 \%$ mixture is $3.28 \mathrm{MPa}$. Strong press for substitution 25\% wood ash larger 26,37\% that is 4,14 MPa and object of test with substitution $50 \%$ decrease $12,46 \%$ that is $2,87 \mathrm{MPa}$.
\end{abstract}

Kata Kunci: Ash mahogany powder, aggregate, lightweight concrete brick.

\begin{abstract}
ABSTRAK
Kota Blitar mengalami perkembangan yang cukup pesat di bidang perdagangan. Salah satunya adalah industri kerajinan dari kayu, terutama kendang jimbe. Daerah yang cukup terkenal sebagai penghasil jimbe kendang adalah Desa Tanggung, Kecamatan Kepanjenkidul, Kota Blitar. Di daerah ini sebagian besar orang bekerja sebagai pengrajin kendang, juga merupakan pusat kerajinan bubut di Kota Blitar. Pada dasarnya, orang Blitar mendapatkan dari kegiatan ini, dalam hal ini orang tidak dapat memanfaatkan sisa kegiatan, terutama pemanfaatan abu pembakaran serbuk mahoni. Dari abu yang melimpah dari pembakaran kayu mahoni diharapkan dapat digunakan sebagai campuran tambahan beton ringan. Metode yang digunakan dalam penelitian ini menggunakan eksperimen laboratorium dan dipandu pada SNI 03-0691-2000. Campuran debu abu mahoni, dan mengetahui kekuatan tekan bata ringan dengan material abu debu sebagai bahan pasir tambahan 0\%, 25\%, 50\%. Dari perbandingan ini dapat dihasilkan sebagai berikut: Penggunaan abu abu mahoni kering menambah bahan agregat halus (pasir) dalam campuran bata beton pada umur 7 hari untuk campuran $0 \%$ adalah 3,28 MPa. Pers yang kuat untuk substitusi $25 \%$ abu kayu lebih besar 26,37\% yaitu 4,14 MPa dan objek uji dengan substitusi $50 \%$ turun $12,46 \%$ yaitu $2,87 \mathrm{MPa}$.
\end{abstract}

\section{Kata Kunci: Abu Mahoni, Agregat, Bata Ringan}

Kota Blitar mengalami perkembangan yang cukup pesat dibidang perdagangan. Salah satunya adalah industri kerajinan dari bahan kayu, terutama kendang jimbe. Daerah yang cukup terkenal sebagai penghasil kendang jimbe adalah Kelurahan Tanggung, Kecamatan Kepanjenkidul, Kota Blitar. Di daerah ini sebagian besar masyarakatnya berprofesi sebagai pengrajin kendang, juga merupakan sentra kerajinan bubut di Kota Blitar. Pada dasarnya masyarakat Blitar berpengasilan dari kegiatan tersebut, dalam hal ini masyarakat belum bisa memanfaatkan dengan baik dari sisa kegiatan tersebut, terutama pemanfaatan abu sisa pembakaran serbuk kayu mahoni. Dari banyaknya abu sisa pembakaran kayu mahoni tersebut di harapkan dapat dijadikan bahan campuran tambahan pada pembuatan beton ringan.

Bata ringan atau disebut hebel atau celcon. Material bata ringan ini pembuatannya sudah sangat modern dimana material ini dibuat dengan menggunakan mesin pabrik. Bata ini cukup ringan, halus dan memilki tingkat kerataan yang baik. Bata ringan ini diciptakan agar dapat memperingan beban struktur dari sebuah bangunan konstruksi, mempercepat pelaksanaan, serta meminimalisasi sisa material yang terjadi pada saat proses pemasangan dinding berlangsung. 
Jurnal Qua Teknika, Vol. 8 No. 1 Maret 2018

p-ISSN: 2088-2424; e-ISSN: 2527-3892

Fakultas Teknik Universitas Islam Balitar, Blitar

Http://qua.unisbablitar.ejournal.web.id; Email; quateknika@Gmail.com

Achendri M. Kurniawan, Sindy Sunjaya. 2018. Penambahan abu padam serbuk kayu mahoni sisa pemasakan tahu sebagai bahan imbuh pasir dalam meningkatkan kuat tekan bata ringan.

Jurnal Qua Teknika, (2018), 8 (1) : 42-53

Serbuk gergaji atau serbuk kayu merupakan limbah industry penggergajian kayu. Selama ini limbah serbuk kayu banyak menimbulkan masalah dalam penanganannya yang selama ini dibiarkan membusuk, ditumpuk dan dibakar yang kesemuanya berdampak negatif terhadap lingkungan sehingga penanggulangannya perlu dipikirkan. Salah satu jalan yang dapat ditempuh adalah memanfaatkannya menjadi produk yang bernilai tambah dengan teknologi aplikatif dan kerakyatan sehingga hasilnya mudah disosialisasikan kepada masyarakat

Kandungan kimia kayu adalah selulosa $\pm 60 \%$, lignin $\pm 28 \%$ dan zat lain (termasuk zat gula) $\pm 12 \%$. Dinding sel tersusun sebagaian besar oleh selulosa(C6H10O5). Lignin adalah suatu campuran zat-zat organik yang terdiri dari zat karbon (C), zat air (H2) dan oksigen (O2). Serbuk gergaji kayu mengandung komponen utama selulosa, hemiselulosa, lignin dan zatekstraktif kayu.

Abu tanaman adalah material (umumnya berupa bubuk) yang tersisa setelah pembakaran kayu. Umumnya, 6$10 \%$ massa kayu yang dibakar menghasilkan abu. Komposisi abu dipengaruhi oleh jenis kayu yang dibakar. Kondisi pembakaran juga mempengaruhi komposisi abu dan jumlah abu yang tersisa, temperatur yang tinggi akan mengurangi jumlah abu yang dihasilkan. ( di Lis Ayu Widari, dkk )

Abu layang termasuk bahan pozolan buatan [lea. FM 1971(dalam Yatti S. Hidayat,1993)]. Karena sifatnya yang pozolanic, sehingga abu layang dapat dimanfaatkan sebagai bahan pengganti sebagian pemakaian semen, baik untuk adukan maupun untuk campuran beton. Keuntungan lain dari abu layang yang mutunya baik ialah dapat meningkatkan ketahanan / keawetan beton terhadap ion sulfat dan juga dapat menurunkan panas hidrasi semen.

Berdasarkan uraian diatas, maka dilakukan penelitian untuk mengetahui Bagai mana pengaruh bahan tambah abu serbuk kayu pada kuat tekan bata ringan.

\section{METODE PENELITIAN}

Penelitian ini untuk mengetahui kuat tekan bata ringan dengan menggunakan bahan tambah abu serbuk kayu mahoni sisa pembakaran pemasakan tahu sebagai bahan tambah pasir. Pembuatan bata ringan dengan campuran semen, pasir dan abu sebagai bahan tambah. Menggunakan 9 sempel terdiri dari 3 sempel tanpa campuran abu untuk acuan, 3 sempel ditambah dengan abu sebanyak 25\% dan 3 sempel berikutnya ditambah dengan 50\% abu sebagai bahan tambah pasir. Abu yang dibuat untuk praktikum kali ini berasal dari sisa serbuk kayu mahoni sisa pemasakan tahu didaerah pakunden kota Blitar. Pelaksanaan praktikum bertempat di Universitas Tribhuwana Tunggadewi Malang. Pelaksanaan praktik pada tanggal 03 Oktober 2017 sampai 17 Oktober 2017.

Penelitian ini bertujuan untuk mengetahui kuat tekan bata ringan dengan campuran abu serbuk kayu mahoni, dan mengetahi kuat tekan bata ringan dengan bahan tabah abu serbuk kayu sebagai bahan tambah pasir sebanyak 0\%, 25\%, 50\%. Pengujian dilakukan di laboratorium Universitas Tribhuwana Tunggadewi Malang. Sebelum pengujian dilaksanakan, dilakukan pengumpulan bahan terlebih dahulu. Setelah itu dilakukan uji bahan untuk mengetahui gradasi pasir, kadar air yang terkandung dalam pasir, serapan air, berat jenis pasir. Setelah pengumpulan bahan selesai, dilakukan pengayakan dan pembersihan abu dari bahan yang lain. Setelah selesai baru beranjak pada mix design dan pembuatan adonan dan pencetakan. Setelah pencetakan selesai, setelah benda uji berumur 1 hari dan di angina-anginkan tidak langsung dijemur dibawah sinar matahari selama 7 hari. Setelah proses perawatan selesai benda uji bisa di uji tekan untuk mengetahui kuat tekan benda uji. Pembuatan benda uji berdasarkan variasi penambahan abu serbuk kayu mahoni. Pada table 1.1 dibawah ini memperlihatkan variasi dan juga jumlah benda uji yang akan dibuat dalam penelitian ini.

Tabel 1.1. Variasi dan Jumlah Benda Uji

\begin{tabular}{|c|c|c|c|}
\hline No & Nama & $\begin{array}{c}\text { Persentase Abu Serbuk } \\
\text { Kayu Mahoni }\end{array}$ & $\begin{array}{c}\text { Jumlah } \\
\text { Benda Uji }\end{array}$ \\
\hline 1 & BBT 1 & $0 \%$ & 3 \\
\hline 2 & BBT 2 & $25 \%$ & 3 \\
\hline 3 & BBT 3 & $50 \%$ & 3 \\
\hline & \multicolumn{3}{|c|}{ Jumlah } \\
\hline
\end{tabular}

Prosedur pelaksanaan penelitian digambarkan dalam diagram alir dibawah ini 
Achendri M. Kurniawan, Sindy Sunjaya. 2018. Penambahan abu padam serbuk kayu mahoni sisa pemasakan tahu sebagai bahan imbuh pasir dalam meningkatkan kuat tekan bata ringan.

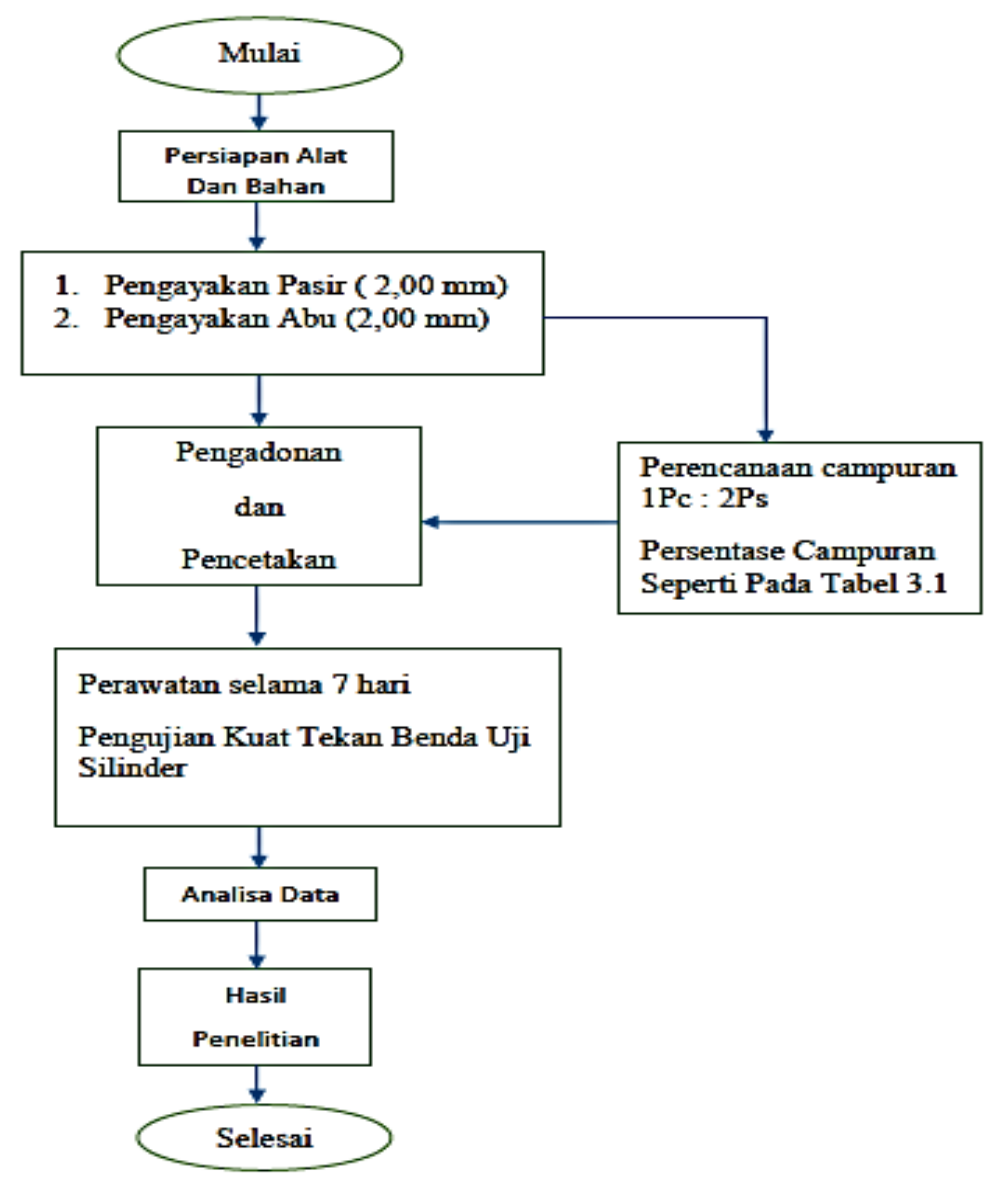

Gambar 1.1 Alir tahapan penelitian

Pembuatan bata ringan dengan bahan tambah abu serbuk kayu. Benda uji berbentuk balok dengan ukuran $15 \mathrm{~cm} \times 15 \mathrm{~cm} \times 15 \mathrm{~cm}$. Dengan menggunakan bahan tambah abu serbuk mahoni dengan campuran bahan tambah sebanyak 0\%, 25\%,50\%. Benda uji berjumlah 9 benda uji, untuk 0\% sebanyak 3 benda uji, 25\% sebanyak 3 benda uji, $50 \%$ sebanyak 3 benda uji.

Dalam penelitian ini menggunakan metode eksperimen, bertujuan untuk mengetahui kuat tekan pada bata ringan dengan bahan tambah abu.

1. Kadar Air Agregat

$\mathrm{W} 3=\mathrm{W} 2-\mathrm{W} 1$

$\mathrm{W} 5=\mathrm{W} 4-\mathrm{W} 1$

Kadar air agregat $=\frac{\left(W_{3}-W_{\mathrm{S}}\right)}{W_{5}} \times 100 \%$

Dimana :

$\mathrm{W} 1=$ Berat talam

$\mathrm{W} 2$ = Benda uji + Talam

$\mathrm{W} 3=$ Berat benda uji

$\mathrm{W} 4$ = Berat benda uji + talam setelah di oven

W5 = Berat benda uji kering

2. Berat jenis dan penyerapan air agregat halus

a. Berat jenis curah

Berat jenis curah $=\frac{B_{k}}{\left(B+500-B_{\mathrm{r}}\right)}$

b. Berat jenis jenuh kering permukaan 
Berat jenis jenuh keing permukaan $=\frac{500}{\left(B+500-B_{q}\right)}$

c. Berat jenis semu

$$
\text { Berat jenis semu }=\frac{B_{k}}{\left(B+B_{k}-B_{k}\right)}
$$

d. Penyerapan air

$$
\text { Penyerapan air }=\frac{500-B_{k}}{B_{k}} \times 100 \%
$$

Dimana :

$\mathrm{Bk}=$ berat benda uji kering oven ( $\mathrm{gr}$ )

$\mathrm{B}=$ berat piknometer berisi air (gr)

$\mathrm{Bt}=$ berat piknometer berisi benda uji dan air (gr)

$500=$ berat benda uji dalam keadaan ssd (gr)

3. Berat volume benda uji

\section{Berat volume $(B v)=\frac{\boldsymbol{w}}{\boldsymbol{v}}$}

Dimana :

$\mathrm{Bv}=$ berat volume benda uji

$\mathrm{W}=$ berat benda uji (gr)

$\mathrm{V}=$ volume benda uji $(\mathrm{cm} 3)$

4. Kuat tekan benda uji

Dimana :

$$
f_{c}=\frac{P}{A}
$$

$f_{c}=$ Kuat tekan $(\mathrm{N} / \mathrm{mm})$

$\mathrm{P}=$ gaya tekan maksimum $(\mathrm{N})$

$\mathrm{A}=$ luas penampang benda uji (mm2)

\section{HASIL DAN PEMBAHASAN}

\section{Pemeriksaaan Gradasi Agregat Halus}

Tabel 1.2. Analisa gradasi agregat halus

\begin{tabular}{|c|c|c|}
\hline \multicolumn{2}{|c|}{ Lubang Saringan } & Pasir \\
\cline { 3 - 3 } No & Mm & Tertinggal \\
\hline $3^{n}$ & 76.2 & Gram \\
\hline $2.5^{n}$ & 63.5 & - \\
\hline $2^{n}$ & 50.8 & - \\
\hline $1.5^{n}$ & 38.1 & - \\
\hline $1^{n}$ & 25.4 & - \\
\hline $3 / 4^{n}$ & 19.1 & - \\
\hline $1 / 2^{n}$ & 12.7 & - \\
\hline $3 / 8^{n}$ & 9.5 & - \\
\hline 4 & 4.76 & - \\
\hline 8 & 2.38 & 0 \\
\hline 16 & 1.19 & 152.20 \\
\hline 30 & 0.59 & 119 \\
\hline 50 & 0.297 & 313.8 \\
\hline 100 & 0.149 & 179.6 \\
\hline 200 & 0.075 & 143.4 \\
\hline Pan & & 22.2 \\
\hline$\Sigma=$ & & 4.2 \\
\hline
\end{tabular}


Achendri M. Kurniawan, Sindy Sunjaya. 2018. Penambahan abu padam serbuk kayu mahoni sisa pemasakan tahu sebagai bahan imbuh pasir dalam meningkatkan kuat tekan bata ringan.

Jurnal Qua Teknika, (2018), 8 (1) : 42-53

Pemeriksaan gradasi agregat halus terlihat pada saringan no $4(4,76 \mathrm{~mm})$ agregat halus lolos semua, pada saringan no $8(2,38 \mathrm{~mm})$ tertinggal seberat 152,20 gr sebanyak $16,362 \%$, pada saringan no $16(1,19 \mathrm{~mm})$ berat tertinggal sebesar 119 gr sebanyak $12,793 \%$, untuk saringan no $30(0,59 \mathrm{~mm})$ berat tertinggal sebesar 313,8 gr sebanyak 33,735\%, untuk saringan no $50(0,297 \mathrm{~mm})$ tertinggal sebesar 179,6 gr sebanyak $19,308 \%$, untuk saringan no $100(0,149 \mathrm{~mm})$ berat tertinggal 143,4 gr sebanyak $15,416 \%$, untuk saringan no $200(0,075 \mathrm{~mm})$ berat tertinggal sebesar 22,2 gr sebanyak 2,387\%, untuk pan berat tertinggal sebesar 4,2 gr sebanyak 0,452\%. Juga bisa dilihat persentase berat yang tertinggal yaitu untuk persentase komulatif tertinggal dan persentase komulatif lolos.

\section{Pemeriksaan Kadar Air Agregat}

Pemeriksaan kadar air agregat ini bertujuan untuk mengetahui angka prosentase kadar air yang dikandung agregat. Pelaksanaan pengujian kadar air dengan menggunakan 5 sempel dengan jenis pasir yang sama yaitu pasir dari lumajang. Pelaksanaan pengujian kadar air dilaksanakan sebagai berikut :

Tabel 1.3. Hasil Pengujian Kadar Air

\begin{tabular}{|c|c|c|c|c|c|c|c|}
\hline \multicolumn{3}{|c|}{ Nomor Contoh } & \multicolumn{5}{|c|}{1} \\
\hline \multicolumn{3}{|c|}{ Nomor Talam } & A & B & $\mathbf{C}$ & D & $\mathbf{E}$ \\
\hline 1 & Berat Talam + Contoh basah & (gr) & 23.6 & 25.6 & 26.2 & 25.6 & 22.8 \\
\hline 2 & Berat Talam + Contoh kering & (gr) & 23.4 & 25.6 & 26 & 25.4 & 22.6 \\
\hline 3 & Berat Air $=\left(1 \mathcal{H}^{\prime}(2)\right.$ & (gr) & 0.2 & 0.0 & 0.2 & 0.2 & 0.2 \\
\hline 4 & Berat Talam & (gr) & 3.2 & 3.2 & 3.2 & 3.2 & 3.2 \\
\hline 5 & Berat Contoh Kering $=(2)-(4)$ & (gr) & 20.2 & 22.4 & 22.8 & 22.2 & 19.4 \\
\hline
\end{tabular}

Untuk berat talam semua sama yaitu 3,2 gr, sedangkan untuk berat talam ditambah contoh basah untuk setiap sampel bisa dilihat pada no 1 . Setelah benda uji dan talam di oven menghasilkan berat talam ditambah benda uji kering untuk setiap sampel bisa dilihat pada no 2. Untuk perhitungan berat air bisa dilihat pada no 3 dan untuk berat sampel kering bisa dilihat pada no 5 .

\section{Berat Jenis dan Penyerapan Air pada Agregat Halus}

Harga berat jenis curah, berat jenis jenuh kering permukaan (ssd) dan berat jenis semu. Mendapatkan harga penyerapan air pada agregat halus.

Tabel 1.4. Hasil Pengujian Berat Jenis dan Penyerapan Agregat Halus

\begin{tabular}{|l|c|c|c|}
\hline NOMOR CONTOH & & & A \\
\hline Berat benda uji kering permukaan jenuh & 500 & (gr) & 500 \\
\hline Berat benda uji kering oven & Bk & (gr) & 492.8 \\
\hline Berat piknometer berisi air & B & (gr) & 676 \\
\hline Berat piknometer + benda uji (ssd) + air (pd suhu kamar) & Bt & (gr) & 988.2 \\
\hline
\end{tabular}

Dari proses pengujian yang dilakukan memperoleh hasil laboratorium pada tabel diatas dengan menggunakan berat benda uji sebesar 500gr berat benda uji setelah di oven atau kering oven sebesar 492,8 gr, berat piknometer berisi air sebesar 676 gr, dan berat piknometer berisi benda uji ssd dan air sebesar 988,2 gr.

\section{Pemeriksaan Berat Isi Agregat}

Untuk mengetahui berat isi agregat halus, berat suatu pasir adalah perbandingan antara pasir dengan volume alat ukur. Unit weight diperoleh dengan memasukkan pasir kedalam alat ukur yang telah diketahui volumenya sehingga berat pasir dapat diketahui. Jika pasir yang dimasukkan kedalam benda uji ditusuk-tusuk sebanyak 25 kali dengan tongkat tusuk, maka cara ini disebut rodding. Jika pasir yang dimasukkan kedalam alat ukur dengan cara biasa (tidak ditusuk-tusuk), maka cara ini dinamakan shoveling. Mendapatkan hasil sebagai tabel 1.5. 
Jurnal Qua Teknika, Vol. 8 No. 1 Maret 2018

p-ISSN: 2088-2424; e-ISSN: 2527-3892

Fakultas Teknik Universitas Islam Balitar, Blitar

Http://qua.unisbablitar.ejournal.web.id; Email; quateknika@Gmail.com

Achendri M. Kurniawan, Sindy Sunjaya. 2018. Penambahan abu padam serbuk kayu mahoni sisa pemasakan tahu sebagai bahan imbuh pasir dalam meningkatkan kuat tekan bata ringan.

Jurnal Qua Teknika, (2018), 8 (1) : 42-53

Tabel 1.5. Hasil Pengujian Berat Isi Agregat

\begin{tabular}{|c|l|r|r|r|}
\hline \multicolumn{2}{|c|}{ No Contoh } & \multicolumn{3}{c|}{ A } \\
\hline 1 & Berat Takaran & gr & 3200 & 3200 \\
\hline 2 & Berat Takaran + Air & gr & 4000 & 4000 \\
\hline 3 & Berat Air & gr & 800 & 800 \\
\hline 4 & Volume Air & cc & 0.25 & 0.25 \\
\hline & CARA & & RODDED & SHOVELED \\
\hline 5 & Berat Takaran & gr & 3200 & 3200 \\
\hline 6 & Berat Takaran + Benda Uji & gr & 4400 & 4200 \\
\hline 7 & Berat Benda Uji & gr & 1200 & 1000 \\
\hline 8 & Berat Isi Agregat Halus & gr/cc & 4800 & 4000 \\
\hline 9 & Berat Agregat Halus Rata-Rata & gr/cc & \multicolumn{2}{|c|}{4400} \\
\hline
\end{tabular}

\section{Rencana Mix-design}

Perencanaan mixdesign awal menggunakan perbandingan campuran 1pc:2ps. Untuk mixdesign awal biasa dilihat pada tabel 1.6.

Tabel 1.6 Rencana Kira-Kira Mixdesign awal

\begin{tabular}{|c|c|c|}
\hline No & Bahan & Berat ( gr ) \\
\hline 1 & Semen & 1110 \\
\hline 2 & Pair & 1850 \\
\hline 3 & Air & 520 \\
\hline 4 & Busa & 300 \\
\hline
\end{tabular}

Dari hasil mixdesign pada tabel 1.6 diatas tidak bisa digunakan karena campuran busa terlalu banyak serta pasir dan semen terlalu sedikit. Busa yang terlalu banyak tidak bisa menahan berat pasir dan semen dan juga penguapan busa terlalu cepat. Untuk hasil bisa dilihat pada gambar dibawah ini :

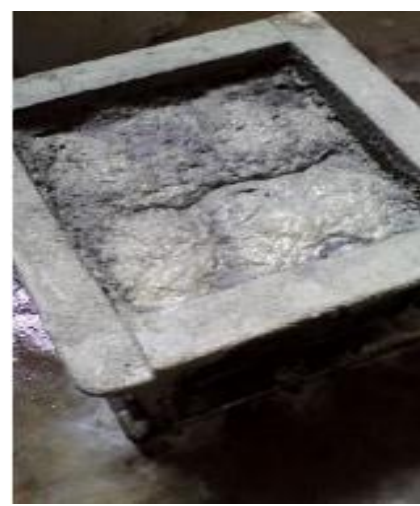

Gambar 1.2 gambar penyusutan mixsdesign pertama 
Achendri M. Kurniawan, Sindy Sunjaya. 2018. Penambahan abu padam serbuk kayu mahoni sisa pemasakan tahu sebagai bahan imbuh pasir dalam meningkatkan kuat tekan bata ringan.

Jurnal Qua Teknika, (2018), 8 (1) : 42-53

Setelah melihat ,hasil dari mix design yang pertama maka benda uji tidak bisa digunakan, percobaan mixdesign yang kedua saya menggunakan campuran pada tabel dibawah ini.

Tabel 1.7 Rencana Kira-Kira Mixsdesig ke 2

\begin{tabular}{|c|c|c|}
\hline No & Bahan & Berat (gr) \\
\hline 1 & Semen & 1110 \\
\hline 2 & Pair & 1850 \\
\hline 3 & Air & 520 \\
\hline 4 & Busa & 100 \\
\hline
\end{tabular}

Dari hasil mixdesign pada tabel 1.7 diatas tidak bisa digunakan karena campuran pasir dan semen terlalu sedikit. Untuk hasi benda uji berukuran $15 \mathrm{~cm} \times 15 \mathrm{~cm} \times 9 \mathrm{~cm}$ dengan berat awal $3,3 \mathrm{~kg}$ setelah melalui proses pengeringan berat mencapai $3 \mathrm{~kg}$. Setelah di uji tekan, mampu menerima gaya tekan sebesar 38,6 Kn. Sehingga menghasilkan kuat tekan sebesar 4,39 MPa.

Dari hasil percobaan yang dilakukan pada mixsdesign pertama dan kedua maka rencana campuran pada penelitian ini adalah untuk pencapaian kuat tekan mencapai $3 \mathrm{Mpa}$. Untuk perencanaan mix design kebutuhan bahan kira-kira untuk 1 buah benda uji dengan ukuran $15 \mathrm{~cm} \times 15 \mathrm{~cm} \times 15 \mathrm{~cm}$ bisa dilihat pada tabel.

Tabel 1.8 Rencana Mix-design untuk 1 Buah Benda Uji Berukuran $15 \mathrm{~cm} \times 15 \mathrm{~cm} \times 15 \mathrm{~cm}$.

\begin{tabular}{|c|l|c|c|c|}
\hline \multirow{2}{*}{ No } & \multirow{2}{*}{ Komponen } & \multicolumn{3}{|c|}{ Kategori berat volume kira-kira } \\
\cline { 3 - 5 } & & $0 \%$ & $25 \%$ & $50 \%$ \\
\hline 1 & Pasir ( Kg) & 3,32 & 2,49 & 1,66 \\
\hline 2 & Semen ( Kg) & 1,61 & 1,61 & 1,61 \\
\hline 3 & Air ( Kg) & 0.71 & 0,71 & 0,71 \\
\hline 4 & Abu (Kg) & - & 0.83 & 1,66 \\
\hline 5 & Foam ( gr) & 100 & 100 & 100 \\
\hline
\end{tabular}

Tabel 1.9 Tabel berat satuan abu

\begin{tabular}{|c|c|c|c|c|c|c|c|c|}
\hline \multirow[b]{2}{*}{ No } & \multirow{2}{*}{$\begin{array}{l}\text { Konsentrasi } \\
\text { Abu Dalam } \\
\text { Campuran }\end{array}$} & \multirow[b]{2}{*}{$\begin{array}{c}\text { Benda } \\
\mathbf{U}_{\mathrm{ji}}\end{array}$} & \multicolumn{3}{|c|}{ Dimensi } & \multirow[b]{2}{*}{$\begin{array}{c}\text { Volume } \\
\left(\mathrm{cm}^{3}\right)\end{array}$} & \multirow{2}{*}{$\begin{array}{c}\text { Kebutuhan } \\
\text { Abu } \\
\text { gr }\end{array}$} & \multirow{2}{*}{$\begin{array}{c}\text { Berat } \\
\text { Volume Abu } \\
\mathrm{g} / \mathrm{cm}^{3}\end{array}$} \\
\hline & & & $\begin{array}{c}\mathbf{t} \\
\mathrm{cm}\end{array}$ & $\begin{array}{c}\mathbf{p} \\
\mathrm{cm}\end{array}$ & $\begin{array}{c}\mathrm{h} \\
\mathrm{cm}\end{array}$ & & & \\
\hline \multirow{3}{*}{1} & \multirow{3}{*}{$0 \%$} & 1 & 15 & 15 & 15 & 3375 & - & - \\
\hline & & 2 & 15 & 15 & 15 & 3375 & - & - \\
\hline & & 3 & 15 & 15 & 15 & 3375 & - & - \\
\hline \multirow{3}{*}{2} & \multirow{3}{*}{$25 \%$} & 1 & 15 & 15 & 15 & 3375 & 830 & 0.25 \\
\hline & & 2 & 15 & 15 & 15 & 3375 & 830 & 0.25 \\
\hline & & 3 & 15 & 15 & 15 & 3375 & 830 & 0.25 \\
\hline \multirow{3}{*}{3} & \multirow{3}{*}{$50 \%$} & 1 & 15 & 15 & 15 & 3375 & 1660 & 0.49 \\
\hline & & 2 & 15 & 15 & 15 & 3375 & 1660 & 0.49 \\
\hline & & 3 & 15 & 15 & 15 & 3375 & 1660 & 0.49 \\
\hline
\end{tabular}


Jurnal Qua Teknika, Vol. 8 No. 1 Maret 2018

p-ISSN: 2088-2424; e-ISSN: 2527-3892

Fakultas Teknik Universitas Islam Balitar, Blitar

Http://qua.unisbablitar.ejournal.web.id; Email; quateknika@Gmail.com

Achendri M. Kurniawan, Sindy Sunjaya. 2018. Penambahan abu padam serbuk kayu mahoni sisa pemasakan tahu sebagai bahan imbuh pasir dalam meningkatkan kuat tekan bata ringan.

Jurnal Qua Teknika, (2018), 8 (1) : 42-53

Tabel 1.10 Berat sebelum pengikatan

\begin{tabular}{|c|c|c|c|c|c|c|c|c|}
\hline \multirow[t]{2}{*}{ No } & \multirow{2}{*}{$\begin{array}{l}\text { Konsentrasi } \\
\text { Abu Dalam } \\
\text { Campuran }\end{array}$} & \multirow{2}{*}{$\begin{array}{c}\text { Benda } \\
\text { Uji }\end{array}$} & Semen & Pasir & Abu & $\mathrm{Ai}$ & Foam & $\begin{array}{c}\text { Kebutuhan } \\
\text { Bahan } 1 \\
\end{array}$ \\
\hline & & & g & g्र & g & gr & $\mathrm{g}$ & gI \\
\hline \multirow{3}{*}{1} & \multirow{3}{*}{$0 \%$} & 1 & 1610 & 3320 & - & 710 & 100 & 5740 \\
\hline & & 2 & 1610 & 3320 & - & 710 & 100 & 5740 \\
\hline & & 3 & 1610 & 3320 & - & 710 & 100 & 5740 \\
\hline \multirow{3}{*}{2} & \multirow{3}{*}{$25 \%$} & 1 & 1610 & 2490 & 830 & 710 & 100 & 5740 \\
\hline & & 2 & 1610 & 2490 & 830 & 710 & 100 & 5740 \\
\hline & & 3 & 1610 & 2490 & 830 & 710 & 100 & 5740 \\
\hline \multirow{3}{*}{3} & \multirow{3}{*}{$50 \%$} & 1 & 1610 & 1660 & 1660 & 710 & 100 & 5740 \\
\hline & & 2 & 1610 & 1660 & 1660 & 710 & 100 & 5740 \\
\hline & & 3 & 1610 & 1660 & 1660 & 710 & 100 & 5740 \\
\hline \multicolumn{3}{|c|}{$\mathrm{h}$ Kebutuhan $B$} & 14490 & 22410 & 7470 & 6390 & 900 & 51660 \\
\hline
\end{tabular}

\section{Hasil Berat Benda Uji dan Volume}

Setelah proses curing selama 7 hari dan sebelum pengujian tekanan, sempel di lakukan pengukuran imensi dan penimbangan terlebih dahulu guna menghitung berat volume yang di dapat pada benda uji. Hasil dari pengukuran dimensi dari benda uji dan penimbangan berat benda uji. Untuk hasil penimbangan berat benda uji bisa di lihat pada tabel 1.9 dan sedangkan untuk dimensi benda uji bisa dilihat pada tabel 1.11.

Tabel 1.11 Hasil Berat Benda Uji

\begin{tabular}{|c|c|c|c|c|}
\hline No & $\begin{array}{l}\text { Konsentrasi } \\
\text { Abu Dalam } \\
\text { Campuran }\end{array}$ & $\begin{array}{c}\text { Benda } \\
\mathbf{U}_{\mathrm{ji}}\end{array}$ & $\begin{array}{c}\text { Berat } \\
\text { Benda Uji } \\
\text { gy }\end{array}$ & $\begin{array}{c}\text { Berat } \\
\text { Rata-Rata } \\
\text { gr }\end{array}$ \\
\hline \multirow{3}{*}{1} & \multirow{3}{*}{$0 \%$} & 1 & 4785 & \multirow{3}{*}{4618.33} \\
\hline & & 2 & 4650 & \\
\hline & & 3 & 4420 & \\
\hline \multirow{3}{*}{2} & \multirow{3}{*}{$25 \%$} & 1 & 5355 & \multirow{3}{*}{5401.67} \\
\hline & & 2 & 5430 & \\
\hline & & 3 & 5420 & \\
\hline \multirow{3}{*}{3} & \multirow{3}{*}{$50 \%$} & 1 & 4995 & \multirow{3}{*}{4891.67} \\
\hline & & 2 & 4900 & \\
\hline & & 3 & 4780 & \\
\hline
\end{tabular}

Dari tabel 1.9 diatas bisa dilihat setelah melaluiproses curing atau perawatan mengahsilkan berat per benda uji di setiap substitusi. Untuk berat rata-rata pada substitusi 0\% mencapai 4618,33 gr, sedangkan untuk substitusi $25 \%$ berat nya naik $16,96 \%$ sebanyak 5401,67 gr, sedang kan untuk substitusi $50 \%$ beratnya bertambah $5,92 \%$ lebih besar dari substitusi $0 \%$, tetapi lebih ringan $9,44 \%$ dibandingkan substitusi $25 \%$.

Tabel 1.12 Hasil Pengukuran Dimensi Benda Uji

\begin{tabular}{|c|c|c|c|c|c|c|c|}
\hline \multirow[b]{2}{*}{ No } & \multirow{2}{*}{$\begin{array}{l}\text { Konsentrasi } \\
\text { Abu Dalam } \\
\text { Campuran }\end{array}$} & \multirow[b]{2}{*}{$\begin{array}{c}\text { Benda } \\
\mathrm{Ujji}^{-}\end{array}$} & \multicolumn{3}{|c|}{ Dimensi } & \multirow{2}{*}{$\begin{array}{l}\text { Volume } \\
\left(\mathrm{cm}^{3}\right)\end{array}$} & \multirow{2}{*}{$\begin{array}{c}\text { Volume } \\
\text { Rata-Rata } \\
\left(\mathrm{cm}^{3}\right)\end{array}$} \\
\hline & & & $\stackrel{\mathrm{t}}{\mathrm{cm}}$ & $\begin{array}{c}\mathrm{p} \\
\mathrm{cm}\end{array}$ & $\begin{array}{c}\mathrm{h} \\
\mathrm{cm}\end{array}$ & & \\
\hline \multirow{3}{*}{1} & \multirow{3}{*}{$0 \%$} & 1 & 15 & 15 & 15 & 3375 & \multirow{3}{*}{3375.00} \\
\hline & & 2 & 15 & 15 & 15 & 3375 & \\
\hline & & 3 & 15 & 15 & 15 & 3375 & \\
\hline \multirow{3}{*}{2} & \multirow{3}{*}{$25 \%$} & 1 & 15 & 15 & 15 & 3375 & \multirow{3}{*}{3375.00} \\
\hline & & 2 & 15 & 15 & 15 & 3375 & \\
\hline & & 3 & 15 & 15 & 15 & 3375 & \\
\hline \multirow{3}{*}{3} & \multirow{3}{*}{$50 \%$} & 1 & 15 & 15 & 15 & 3375 & \multirow{3}{*}{3375.00} \\
\hline & & 2 & 15 & 15 & 15 & 3375 & \\
\hline & & 3 & 15 & 15 & 15 & 3375 & \\
\hline
\end{tabular}


Jurnal Qua Teknika, Vol. 8 No. 1 Maret 2018

p-ISSN: 2088-2424; e-ISSN: 2527-3892

Fakultas Teknik Universitas Islam Balitar, Blitar

Http://qua.unisbablitar.ejournal.web.id; Email; quateknika@Gmail.com

Achendri M. Kurniawan, Sindy Sunjaya. 2018. Penambahan abu padam serbuk kayu mahoni sisa pemasakan tahu sebagai bahan imbuh pasir dalam meningkatkan kuat tekan bata ringan.

Jurnal Qua Teknika, (2018), 8 (1) : 42-53

\section{Hasil Uji Kuat Tekan}

Setelah proses curing selesai, dilakukan pengujian tekan pada benda uji. Hasil kuat tekan masing-masing benda uji terlihat pada tabel 1.13 dibawah ini :

Tabel 1.13 Hasil Uji Kuat Tekan

\begin{tabular}{|c|c|c|c|c|c|c|}
\hline \multirow[t]{2}{*}{ No } & \multirow{2}{*}{$\begin{array}{l}\text { Konsentrasi } \\
\text { Abu Dalam } \\
\text { Campuran }\end{array}$} & \multirow[t]{2}{*}{$\begin{array}{c}\text { Benda } \\
\mathbf{U}_{\mathrm{ji}}\end{array}$} & $\begin{array}{l}\text { Gaya } \\
\text { Tekan }\end{array}$ & $\begin{array}{c}\text { Gaya } \\
\text { Tekan } \\
\text { Rata-Rata }\end{array}$ & $\begin{array}{l}\text { Gaya } \\
\text { Tekan }\end{array}$ & $\begin{array}{c}\text { Gaya } \\
\text { Tekan } \\
\text { Rata-Rata }\end{array}$ \\
\hline & & & Kn & $\mathrm{Kn}$ & $\mathrm{N}$ & $\mathbf{N}$ \\
\hline \multirow{3}{*}{1} & \multirow{3}{*}{$0 \%$} & 1 & 52.3 & \multirow{3}{*}{47.90} & 52300 & \multirow{3}{*}{47900.00} \\
\hline & & 2 & 50.3 & & 50300 & \\
\hline & & 3 & 41.1 & & 41100 & \\
\hline \multirow{3}{*}{2} & \multirow{3}{*}{$25 \%$} & 1 & 61.9 & \multirow{3}{*}{60.53} & 61900 & \multirow{3}{*}{60533.33} \\
\hline & & 2 & 55.0 & & 55000 & \\
\hline & & 3 & 64.7 & & 64700 & \\
\hline \multirow{3}{*}{3} & \multirow{3}{*}{$50 \%$} & 1 & 43.1 & \multirow{3}{*}{41.93} & 43100 & \multirow{3}{*}{41933.33} \\
\hline & & 2 & 40.4 & & 40400 & \\
\hline & & 3 & 42.3 & & 42300 & \\
\hline
\end{tabular}

\section{Gradasi Agregat}

Dari hasil .pengayakan pada tabel 1.14 diatas maka setelah diolah menghasilkan data pada tabel 4.12 berikut. Sedangkan modulus halus agregat bisa dilihat pada perhitungan dibawah ini:

Tabel 1.14 Tabel Gradasi Agregat Halus

\begin{tabular}{|c|c|c|c|c|c|}
\hline \multicolumn{2}{|c|}{$\begin{array}{c}\text { Lubang } \\
\text { Saringan }\end{array}$} & Pasir & & \multicolumn{2}{c|}{} \\
\cline { 3 - 6 } & Tertinggal & & \multicolumn{2}{c|}{ \%Kumulatif } \\
\hline no & mm & gram & $\%$ & Tertinggal & Lolos \\
\hline $3^{*}$ & 76.2 & - & - & - & - \\
\hline $2.5^{n}$ & 63.5 & - & - & - & - \\
\hline $2^{*}$ & 50.8 & - & - & - & - \\
\hline $1.5^{n}$ & 38.1 & - & - & - & - \\
\hline $1^{*}$ & 25.4 & - & - & - & - \\
\hline $3 / 4^{n}$ & 19.1 & - & - & - & - \\
\hline $1 / 2^{n}$ & 12.7 & - & - & - & 100 \\
\hline $3 / 8^{n}$ & 9.5 & - & 0.000 & 0.000 & 100.000 \\
\hline 4 & 4.76 & 0 & 16.362 & 16.362 & 83.638 \\
\hline 8 & 2.38 & 152.20 & 12.793 & 29.155 & 70.845 \\
\hline 16 & 1.19 & 119 & 33.735 & 62.890 & 37.110 \\
\hline 30 & 0.59 & 313.8 & 19.308 & 82.197 & 17.803 \\
\hline 50 & 0.297 & 179.6 & 15.416 & 97.613 & 2.387 \\
\hline 100 & 0.149 & 143.4 & 2.387 & 100.000 & 0.000 \\
\hline 200 & 0.075 & 22.2 & 0.452 & - & - \\
\hline Pan & & 4.2 & 100 & 288.218 & \\
\hline$\Sigma=$ & & 930.2 & & & \\
\hline & & & & & - \\
\hline
\end{tabular}

$$
\begin{aligned}
& \text { Modulus halus }=\frac{\sum \% \text { yang tertahan ayakan no } 3 / 8 \text { " sampai no } 100}{100} \\
& \text { Modulus halus }=\frac{288,218}{100}=2,882
\end{aligned}
$$

Dari tabel dan perhitungan diatas maka dapat dihasilkan data persentase benda uji yang lolos pada ukuran saringan 4,76 mm sebesar $100 \%$, pada ukuran saringan 2,38 mm sebesar 83,638\%, pada saringan 1,19 mm sebesar $70,845 \%$, pada saringan $0,59 \mathrm{~mm}$ persentase lolos sebesar $37,110 \%$, pada saringan $0,297 \mathrm{~mm}$ persentase lolos sebesar $17,803 \%$, untuk saringan $0,149 \mathrm{~mm}$ sebesar $2,38 \%$, dan pada $0,075 \mathrm{~mm}$ persentase yang lolos sebesar $0,00 \%$. Maka dari data diatas bisa dibuat grafik sebagai berikut : 
Jurnal Qua Teknika, Vol. 8 No. 1 Maret 2018

p-ISSN: 2088-2424; e-ISSN: 2527-3892

Fakultas Teknik Universitas Islam Balitar, Blitar

Http://qua.unisbablitar.ejournal.web.id; Email; quateknika@Gmail.com

Achendri M. Kurniawan, Sindy Sunjaya. 2018. Penambahan abu padam serbuk kayu mahoni sisa pemasakan tahu sebagai bahan imbuh pasir dalam meningkatkan kuat tekan bata ringan. Jurnal Qua Teknika, (2018), 8 (1) : 42-53

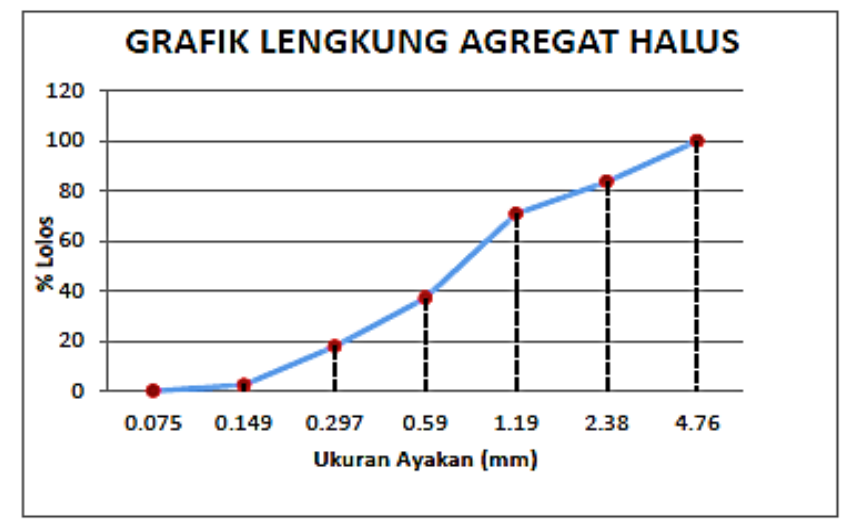

Grafik 1.3 Grafik Lengkung Agreat Halus

Dari grafik diatas maka bisa dilihat alur gradasi yang dihasilkan pada agregat, dari hasilgrafik diatas bisa dimasukkan ke grafik gradasi pasir dan grafik tersebut masuk dalam grafik zoan 1, bisa dilihat pada grafik 1.2.

\section{Kadar Air}

Pengujian kadar air yang ditunjukkan pada tabel 4.2 diatas bisa diolah dan menghasilkan kadar air yaitu bisa dilihat pada tabel 1.13 berikut ini :

Tabel 1.15 Tabel Kadar Air A_gregat

\begin{tabular}{|c|c|c|c|c|c|c|c|}
\hline \multirow{2}{*}{\multicolumn{3}{|c|}{$\begin{array}{l}\text { Nomor Contch } \\
\text { Nomor Talam }\end{array}$}} & \multicolumn{5}{|c|}{1} \\
\hline & & & A & B & $\mathrm{C}$ & D & $\mathrm{E}$ \\
\hline & Berat Talam + Contch basah & (g) & 23.6 & 25.6 & 26.2 & 25.6 & 22.8 \\
\hline 2 & Berat Talam + Contch kering & (g) & 23.4 & 25.6 & 26 & 25.4 & 22.6 \\
\hline & Berat Air $=(1)-(2)$ & (g) & 0.2 & 0.0 & 0.2 & 0.2 & 0.2 \\
\hline 4 & Berat Talam & (g) & 3.2 & 3.2 & 3.2 & 3.2 & 3.2 \\
\hline 5 & Berat Contoh Kering $=(2)-(4)$ & (g) & 20.2 & 2.4 & 22.8 & 22.2 & 19.4 \\
\hline & Kadar Air $=(3 \mathrm{X}(5)$ & (\%) & 0.98 & 0.00 & 0.88 & 0.90 & 1.03 \\
\hline & Kadar Air rata-rata & (\%) & \multicolumn{5}{|c|}{0.76} \\
\hline
\end{tabular}

Dari tabel diatas bisa disimpulkan bahwa persentase kadar air yang terkandung dalam benda uji adalah $0,76 \%$. Kandungan air untuk benda uji sangat sedikit sekali.

Berat Jenis dan Penyerapan Air

Dari hasil pengujian pada tabel 1.15 diatas bisa diolah dan menghasilkan data yang ditunjukkan pada tabel 1.16 dibawah ini :

Tabel 1.16 Tabel Berat Jenis dan Penyerapan Air

\begin{tabular}{|c|c|c|}
\hline NOMOR CONTOH & & A \\
\hline Berat Jenis Curah & \multirow{2}{*}{$\mathrm{Bk} /(\mathrm{B}+500-\mathrm{Bt})$} & \multirow{2}{*}{2.624} \\
\hline (Bulk Spesific Grafity) & & \\
\hline Berat Jenis Kering Permukaan Jenuh & \multirow{2}{*}{$500 /(B+500-B t)$} & \multirow{2}{*}{2.662} \\
\hline (Bulk Spesific Grafity Saturated Surface Dry) & & \\
\hline Berat Jenis Semu & \multirow{2}{*}{$\mathrm{Bk} J(\mathrm{~B}+\mathrm{Bk}-\mathrm{Bt})$} & \multirow{2}{*}{2.729} \\
\hline Apparent Spesific Gravity) & & \\
\hline Penyerapan $(\%)$ & \multirow{2}{*}{$(500-B k) / B k x 100 \%$} & \multirow{2}{*}{1.461} \\
\hline (Absorption) & & \\
\hline
\end{tabular}

Dari tabel 1.14 diatas dapat disimpulkan bahwa agrgat memiliki berat jenis curah sebesar 2,624, memiliki berat jenis kering permukaaan jenuh 2,662, untuk berat jenis semu sebesar 2,729, dan penyerapan air sebesar $1,461 \%$. 
Jurnal Qua Teknika, Vol. 8 No. 1 Maret 2018

p-ISSN: 2088-2424; e-ISSN: 2527-3892

Fakultas Teknik Universitas Islam Balitar, Blitar

Http://qua.unisbablitar.ejournal.web.id; Email; quateknika@Gmail.com

Achendri M. Kurniawan, Sindy Sunjaya. 2018. Penambahan abu padam serbuk kayu mahoni sisa pemasakan tahu sebagai bahan imbuh pasir dalam meningkatkan kuat tekan bata ringan.

Jurnal Qua Teknika, (2018), 8 (1) : 42-53

\section{Hasil Berat Volume}

Pengujian berat volume benda uji pada umur 7 hari sebanyak 3 benda uji untuk setiap sempel, benda uji berbentuk kubus berukuran $15 \mathrm{~cm} \times 15 \mathrm{~cm} \times 15 \mathrm{~cm}$ masing - masing untuk setiap tipe. Hasil pengukuran berat volume bisa dilihat pada Tabel 1.17 .

Tabel 4.17 Hasil Berat Volume Pada Umur 7 Hari

\begin{tabular}{|c|c|c|c|c|c|c|c|c|c|}
\hline \multirow{3}{*}{$\mathrm{N}$} & \multirow{3}{*}{$\begin{array}{l}\text { Konsentrasi } \\
\text { Abu Dakm } \\
\text { Campuran }\end{array}$} & \multirow{3}{*}{$\begin{array}{c}\text { Benda } \\
\text { Uji }\end{array}$} & \multicolumn{3}{|c|}{ Dimensi } & \multirow{2}{*}{ Vohme } & \multirow{2}{*}{$\begin{array}{c}\text { Berat } \\
\text { Benda Uji }\end{array}$} & \multirow{2}{*}{$\begin{array}{c}\text { Berat } \\
\text { Volmme }\end{array}$} & \multirow{2}{*}{$\begin{array}{c}\text { Berat Vohme } \\
\text { Rata-Rata }\end{array}$} \\
\hline & & & $t$ & $p$ & $\mathbf{h}$ & & & & \\
\hline & & & $\mathrm{cm}$ & $\mathrm{cm}$ & $\mathrm{cm}$ & (cm') & gr & (g/cnr') & (g/cmin) \\
\hline \multirow{3}{*}{1} & \multirow{3}{*}{$0 \%$} & 1 & 15 & 15 & 15 & 3375 & 4785 & 1.42 & \multirow{3}{*}{1.37} \\
\hline & & 2 & 15 & 15 & 15 & 3375 & 4650 & 1.38 & \\
\hline & & 3 & 15 & 15 & 15 & 3375 & 4420 & 1.31 & \\
\hline \multirow{3}{*}{2} & \multirow{3}{*}{$25 \%$} & 1 & 15 & 15 & 15 & 3375 & 5355 & 1.59 & \multirow{3}{*}{1.60} \\
\hline & & 2 & 15 & 15 & 15 & 3375 & 5430 & 1.61 & \\
\hline & & 3 & 15 & 15 & 15 & 3375 & 5420 & 1.61 & \\
\hline \multirow{3}{*}{3} & \multirow{3}{*}{$50 \%$} & 1 & 15 & 15 & 15 & 3375 & 4995 & 1.48 & \multirow{3}{*}{1.45} \\
\hline & & 2 & 15 & 15 & 15 & 3375 & 4900 & 1.45 & \\
\hline & & 3 & 15 & 15 & 15 & 3375 & 4780 & 1.42 & \\
\hline
\end{tabular}

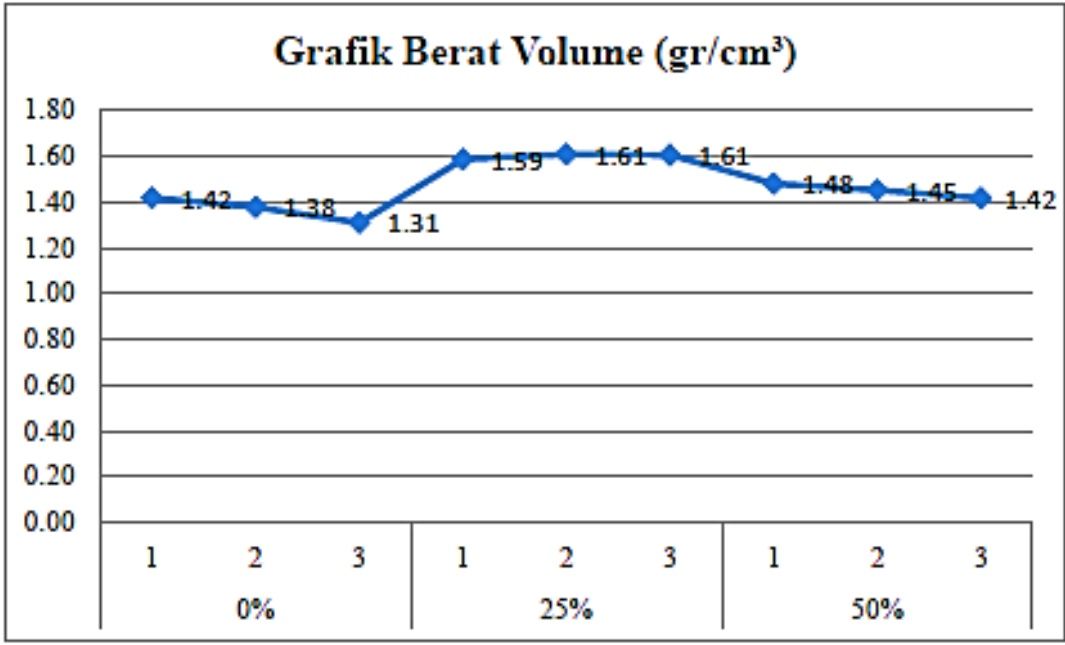

Grafik 1.4 Grafik Berat Volume Pada Umur 7 Hari

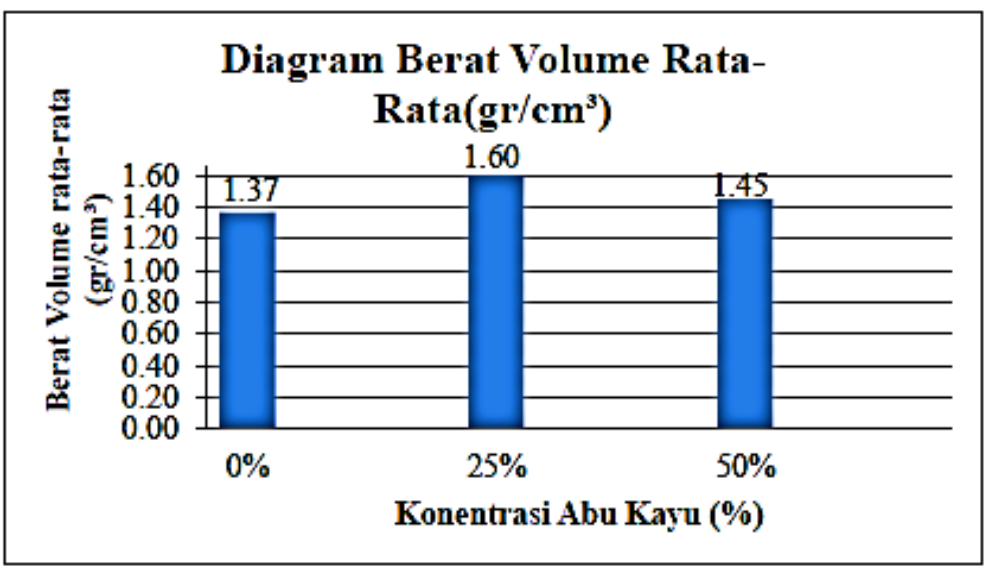

Gambar 1.5 Diagram Berat Volume Rata-Rata 
Jurnal Qua Teknika, Vol. 8 No. 1 Maret 2018

p-ISSN: 2088-2424; e-ISSN: 2527-3892

Fakultas Teknik Universitas Islam Balitar, Blitar

Http://qua.unisbablitar.ejournal.web.id; Email; quateknika@Gmail.com

Achendri M. Kurniawan, Sindy Sunjaya. 2018. Penambahan abu padam serbuk kayu mahoni sisa pemasakan tahu sebagai bahan imbuh pasir dalam meningkatkan kuat tekan bata ringan.

Jurnal Qua Teknika, (2018), 8 (1) : 42-53

Dari grafik diatas bahan tambah abu kayu mahoni mempengaruhi berat jenis bata ringan. Berdasarkan hasil pengujian yang ditampilkan dalam tabel 1.17 dan Gambar 1.5 diatas dapat dilihat bahwa berat voume rata-rata benda uji pada umur 7 hari adalah 1,37 gr/cm3 untuk konsentrasi $0 \%$. Dengan adanya penambahan abu kayu berat volume benda uji lebih besar 16,96\% yaitu 1,60 gr/cm3 pada konsentrasi abu kayu 25\%. Pada substitusi abu kayu dengan konsentrasi $50 \%$ dari volume lebih besar daripada pasir dan untuk berat volume yang dihasilkan lebih besar dari konsentrasi $0 \%$ sebesar 5,92\% yaitu 1,45 gr/cm3 dan 9,44\% lebih kecil dari substitusi dengan konsentrasi abu kayu sebesar $25 \%$.

Hasil Kuat Tekan

Setelah benda uji melalui proses curing selama 7 hari, benda uji di uji tekan dengan alatuji tekan. Pengujian untuk mengetahui kuat tekan benda uji pada umur 7 hari. Hasil pengujian kuat tekan pada umur 7 hari ditampilkan pada tabel 1.18 berikut.

Tabel. 1.18 Hasil Kuat Tekan Benda Uji Pada Umur 7 Hari

\begin{tabular}{|c|c|c|c|c|c|c|c|c|c|}
\hline \multirow{3}{*}{ No } & \multirow{3}{*}{$\begin{array}{c}\text { Konsentr } \\
\text { asi Abu } \\
\text { Dalam }\end{array}$} & \multirow{3}{*}{$\begin{array}{l}\text { Unir } \\
\text { (Hari) }\end{array}$} & \multicolumn{4}{|c|}{ Dimensi } & \multirow{2}{*}{$\begin{array}{l}\text { Gaya } \\
\text { Tekan }\end{array}$} & \multirow{2}{*}{ Kuat Tekan } & \multirow{3}{*}{$\begin{array}{c}\text { Kuat Tekan } \\
\text { Rata-Rata } \\
\text { MPa }\end{array}$} \\
\hline & & & $t$ & $p$ & $\mathrm{~h}$ & Luas & & & \\
\hline & & & $\mathrm{mm}$ & $\mathrm{mm}$ & $\mathrm{mm}$ & $\mathrm{mm}^{2}$ & $\mathrm{~N}$ & $\mathrm{MPa}$ & \\
\hline \multirow{3}{*}{1} & \multirow{3}{*}{$0 \%$} & 7 & 150 & 150 & 150 & 22500 & 52300 & 3.58 & \multirow{3}{*}{3.28} \\
\hline & & 7 & 150 & 150 & 150 & 22500 & 50300 & 3.44 & \\
\hline & & 7 & 150 & 150 & 150 & 22500 & 41100 & 2.81 & \\
\hline \multirow{3}{*}{2} & \multirow{3}{*}{$25 \%$} & 7 & 150 & 150 & 150 & 22500 & 61900 & 4.23 & \multirow{3}{*}{4.14} \\
\hline & & 7 & 150 & 150 & 150 & 22500 & 55000 & 3.76 & \\
\hline & & 7 & 150 & 150 & 150 & 22500 & 64700 & 4.42 & \\
\hline \multirow{3}{*}{3} & \multirow{3}{*}{$50 \%$} & 7 & 150 & 150 & 150 & 22500 & 43100 & 2.95 & \multirow{3}{*}{2.87} \\
\hline & & 7 & 150 & 150 & 150 & 22500 & 40400 & 2.76 & \\
\hline & & 7 & 150 & 150 & 150 & 22500 & 42300 & 2.89 & \\
\hline
\end{tabular}

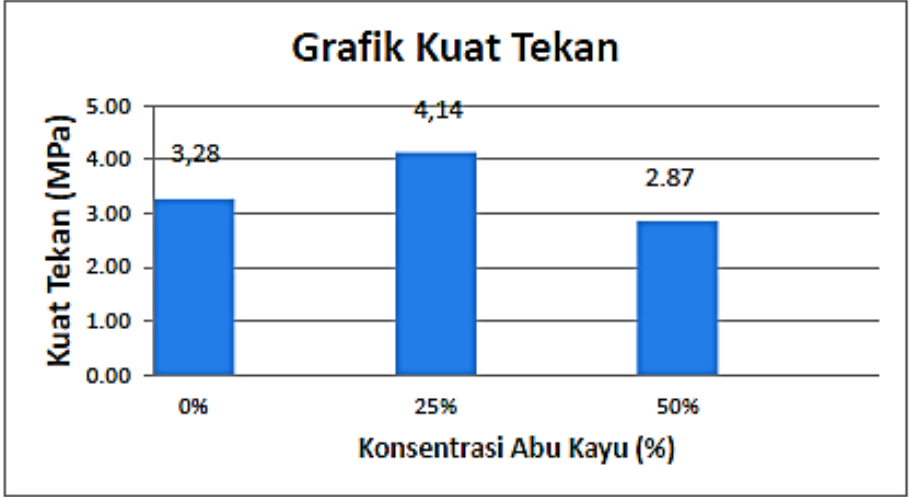

Gambar 1.6 Hubungan fariasi abu dengan kuat tekan

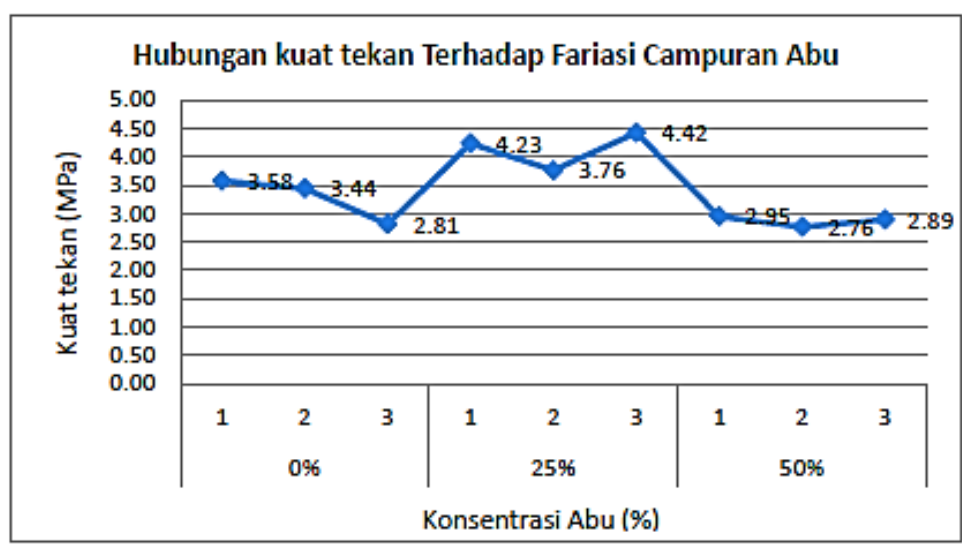

Grafik 1.4 Grafik Kuat Tekan Pada Umur 7 Hari dengan fariasi abu 
Jurnal Qua Teknika, Vol. 8 No. 1 Maret 2018

p-ISSN: 2088-2424; e-ISSN: 2527-3892

Fakultas Teknik Universitas Islam Balitar, Blitar

Http://qua.unisbablitar.ejournal.web.id; Email; quateknika@Gmail.com

Achendri M. Kurniawan, Sindy Sunjaya. 2018. Penambahan abu padam serbuk kayu mahoni sisa pemasakan tahu sebagai bahan imbuh pasir dalam meningkatkan kuat tekan bata ringan.

Jurnal Qua Teknika, (2018), 8 (1) : 42-53

Berdasarkan hasil pengujian yang ditampilkan pada tabel 4.18 dapat dilihat kuat tekan rata-rata benda uji adalah sebesar 3.28 MPa. Untuk penambahan abu kayu sebesar 25\% lebih besar 26,37\% yaitu 4,14 MPa. Sedangkan untuk substitusi abu kayu sebesar 50\% menurun sebesar 12,46\% yaitu 2,87 MPa. Tetapi jika ditinjau dari berat volume substitusi $25 \%$ abu lebih berat daripada yang lain nya. Hal ini menunjukkan bahwa penambahan $25 \%$ menambah kekuatan bata beton sebesar $26,37 \%$ dari campuran $0 \%$ abu, tetapi jika diliat dari berat volume substitusi $25 \%$ lebih berat16,96\% dibandingkan 0\%. Penambahan abu sebesar 50\% kekuatan berkurang 12,46\% dari substitusi $0 \%$, sedangkan dilihat dari berat volume substitusi $50 \%$ lebih berat 5,92\% dari $0 \%$. Untuk penambahan abu sebanyak 25\% akan menambah berat kemungkinan karena volume pasir dan abu sama banyaknya. Tetapi jika penambahan abu ditambah kan 50\% akan menambah sedikit berat volume, tetapi kekuatan juga ikut berkurang kemungkinan dikarenakan terlalu banyak volume abu dibandingkan dengan pasir.

\section{SIMPULAN}

Berdassarkan hasil dari penelitian ini, maka dapat ditarik kesimpulan sebagai berikut :

1. Penggunaan abu kayu mahoni sisa pemasakan tahu sebagai bahan tambah agregat halus ( pasir ) dalam campuran bata beton pada umur 7 hari untuk campuran $0 \%$ adalah 3,28 MPa. Kuat tekan untuk substitusi $25 \%$ abu kayu lebih besar $26,37 \%$ yaitu $4,14 \mathrm{MPa}$ dan benda uji dengan substitusi $50 \%$ mengalami penurunan $12,46 \%$ yaitu $2,87 \mathrm{MPa}$.

2. Penggunaan bahan tambah abu sebanyak $25 \%$ berat volume besar mencapai $1600 \mathrm{~kg} / \mathrm{m} 3$ tetapi kekuatan bertambah mencapai $4,14 \mathrm{MPa}$. Untuk substitusi $50 \%$ berat volume lebih ringan $9,44 \%$ tetapi kuat tekan menurun $30,73 \%$.

Terkait dengan penelitian ini, disarankan perlunya dilakukan penelitian lanjutan dengan melakukan trial error terhadap komposisi bahan penyusun untuk mengetahui komposisi yang tepat dengan nilai kuat tekan optimum dan berat lebih ringan dengan menggunakan abu sebagai agregat.

\section{DAFTAR PUSTAKA}

Lis Ayu Widari, Fasdarsyah,Iva Debrina, Mart 2015, Jurusan Teknik Sipil, Universitas Malikussaleh, Pengaruh Penggunaan Abu Serbuk Kayu Terhadap Kuat Tekan Dan Daya Serap Air Pada Paving Block

Hunggurami ,Elia, Dosen pada Jurusan Teknik Sipil, FST Undana, Wilhelmus Bunganaen, Dosen pada Jurusan Teknik Sipil, FST Undana, Richardo Yeskial Muskanan, Penamat dari Jurusan Teknik Sipil, FST Undana, 2014

Mustain, 2006 diakses di https://harpimandala.files.wordpress.com/2013/11/teknik-sipil_abu-layang.pdf, pada tanggal 30 oktober 2017 